Kolaborasi : Jurnal Administrasi Publik, Desember 2019 Volume 5 Nomor 3

\title{
RELOKASI PEDAGANG KAKI LIMA (PKL) UNTUK MEMPERINDAH KOTA GARUT
}

\author{
Rostiena Pasciana* 1 , Pupung Pundenswari $^{2}$, Gina Sadrina ${ }^{3}$ \\ 1,2,3 Fakultas Ilmu Sosial dan Ilmu Politik Universitas Garut
}

\begin{abstract}
This study aims to evaluate the policy of street vendors relocation program in Garut City. The background of this research is based on the establishment of a policy regarding the relocation program of street vendors in Garut City as an effort to curb street vendors, creating a safe, comfortable and beautiful Garut life plan. In practice, street vendors who have been relocated to the street vendors building are returning to the city center and the number of street vendors is increasing. The method used in this research is descriptive method with a qualitative approach. The location of the study was street vendors in the red zone and the street vendor relocation building. Data obtained by using literature studies and field studies in the form of nonparticipant observation, in-depth interviews and documentation. The sampling method is purposive sampling which is strengthened by the snowball technique. The extension of observation is used as a test of the validity of the data and then the data is reduced, presented and then drawn a conclusion. The results of this study indicate that the evaluation of PKL relocation program policies in Garut City has not yet reached optimal results. The large number of street vendors who return to the red zone and do not want to be relocated makes the street vendor building neglected. Based on the results of the research, the Garut Regency Government is expected to conduct guidance and empowerment routinely, hold a discussion forum between PKL and the Garut Regency Government to find joint solutions, and the relocation building should be immediately taken over by the Regent so that it can be better utilized and managed.
\end{abstract}

Keywords : policy evaluation, public policy, street vendors

\begin{abstract}
Abstrak
Penelitian ini bertujuan untuk mengevaluasi kebijakan program relokasi Pedagang Kaki Lima (PKL) di Garut Kota. Latar belakang penelitian ini didasarkan pada terbentuknya kebijakan mengenai program relokasi PKL di Garut Kota sebagai upaya untuk menertibkan PKL, menciptakan tata kehidupan Garut yang aman, nyaman dan indah. Dalam prakteknya, PKL yang sudah direlokasi ke Gedung PKL kembali lagi ke pusat kota dan jumlah PKL semakin bertambah. Metode yang digunakan dalam penelitian ini adalah metode deskriptif dengan pendekatan kualitatif. Lokasi penelitian adalah di zona merah dan Gedung relokasi PKL. Data diperoleh dengan menggunakan studi kepustakaan dan studi lapangan berupa observasi nonpartisipan, wawancara mendalam dan dokumentasi. Metode penarikan sample yaitu purposive sampling yang dikuatkan dengan teknik snowball. Perpanjangan pengamatan dijadikan sebagai pengujian keabsahan data kemudian data-data tersebut direduksi, disajikan lalu ditarik kesimpulan. Hasil penelitian ini menunjukan evaluasi kebijakan program relokasi PKL di Garut Kota belum mencapai hasil yang optimal. Banyaknya PKL yang kembali ke zona merah dan tidak ingin direlokasi membuat gedung PKL menjadi terbengkalai. Berdasarkan hasil penelitian maka Pemerintah Kabupaten Garut diharapkan melakukan pembinaan dan pemberdayaan secara rutin, mengadakan forum diskusi antara PKL dan Pemerintah Kabupaten Garut untuk mencari solusi bersama, dan hendaknya gedung relokasi segera diambil alih oleh Bupati agar dapat dimanfaatkan dan dikelola lebih baik lagi.
\end{abstract}

Kata kunci: evaluasi kebijakan, kebijakan public, pedagang kaki lima 
Kolaborasi : Jurnal Administrasi Publik, Desember 2019 Volume 5 Nomor 3

\section{PENDAHULUAN}

Pusat kota bagaikan sebuah magnet bagi berkembangnya sektor informal seperti Pedagang Kaki Lima (PKL) karena lingkungan sekitarnya yang di anggap strategis dan merupakan pusat keramaian. Melalui sektor informal ini sekelompok masyarakat mendapatkan penghasilan serta sering kali menjadi peralihan profesi bagi mereka yang semula menjadi korban Pemutusan Hubungan Kerja (PHK). Meskipun menjadi bagian dari sumber perekonomian masyarakat tetapi keberadaan sektor informal ini membawa dampak negatif. Dampak negatif tersebut yaitu terganggunya ketertiban, keindahan serta kenyamanan suatu kota, karena para PKL menjajakan dagangannya di tempat-tempat umum yang tidak diperuntukan sebagai tempat berjualan; seperti trotoar, pinggir jalan, alun-alun atau tempat lainnya. Permasalahan yang diakibatkan dari keberadaan PKL tidak terbatas pada penyalah gunaan fasilitas umum saja tetapi juga mengganggu kebersihan, keindahan, kenyamanan tata ruang kota, bahkan berkaitan dengan permasalahan sosial seperti kemiskinan, pengangguran, keadilan sosial dan kesejahteraan.

Penyelesaian permasalahan PKL harus memperhatikan permasalahan sosial lainnya karena apabila terjadi ketidaksesuaian dan kesalahan dalam penyelesaian terhadap PKL akan menimbulkan permasalahan yang lebih kompleks lagi. Contohnya seperti penanganan dan penertiban PKL oleh pemerintah dengan cara penggusuran secara paksa, dan sering kali ditentang oleh PKL. Adapun alasan pemerintah melakukan penggusuran tersebut karena ketertiban ataupun keindahan kota lebih baik mencari solusi atau alternatif lain seperti menata bangunan-bangunan tempat PKL berjualan atau gerobak dagangan itu dengan bangunan yang pantas dan mewajibkan PKL menjaga kebersihan lingkungan. Seringnya terjadi gesekan antara pedagang kaki lima dengan Pemerintah juga banyak ditemui di kota kota besar (Suripto, 2017). Disisi lain para PKL biasanya membentuk asosiasi atau organisasi dengan tujuan utama melawan gangguan dari pemerintah dan untuk memperjuangkan hak-haknya (Bukhari, 2017). Hal tersebut menjadi bukti bahwa keberadaan PKL selalu menjadi masalah pemerintah, karena tidak seimbangnya jumlah PKL yang berkembang pesat dengan penataan lokasi yang baik. Kesemrawutan lalu lintas serta kenyamanan publik yang terganggu merupakan salah satu dampak adanya PKL di negeri ini. Untuk menjamin terwujudnya ketertiban dan kenyamanan kota, sangatlah penting melakukan penataan PKL sebagai bagian dari penataan ruang kota. (Puspitasari, 2010; Widodo, Idayanti, Permanasari, \& Sahri, 2016). 
Kolaborasi : Jurnal Administrasi Publik, Desember 2019 Volume 5 Nomor 3

Sebagaimana umumnya, Kabupaten Garut yang terletak Jawa Barat dengan jumlah penduduk sebanyak 122.807 jiwa, memiliki permasalahan terkait dengan PKL. Keberadaan PKL di Garut Kota (pusat kota Garut) menimbulkan pro dan kontra. Di satu sisi PKL merupakan roda perekonomian, ladang usaha yang memudahkan masyarakat untuk mendapatkan barang/ makanan dengan harga yang terjangkau. Namun di sisi lain, PKL menimbulkan permasalahanpermasalahan seperti terganggunya ketertiban, kebersihan, dan keindahan yang menjadi salah satu prioritas penanganan oleh pemerintah Garut. Terutama PKL yang menjajakan dagangannya zona merah yaitu jalan Ciledug, jalan Ahmad Yani dan jalan Siliwangi yang mengakibatkan lalu lintas yang tidak teratur baik pergerakan kendaraan di badan jalan maupun pergerakan pejalan kaki di jalur pedestrian (trotoar), menyempitnya badan dan bahu jalan, berkurangnya nilai estetik perkotaan sehingga terkesan kumuh.

Dalam Peraturan Presiden Nomor 125 Tahun 2012 tentang Koordinasi Penataan dan Pemberdayaan PKL, dikemukakan tentang perlunya penataan PKL karena peningkatan jumlah PKL dapat menimbulkan permasalahan-permasalahan. Dengan demikian, Pemerintah Kabupaten Garut menuangkannya dalam Peraturan Daerah Nomor 3 Tahun 2014 tentang
Rencana Pembangunan Jangka Menengah Daerah (RPJMD) Kabupaten Garut Tahun 2014-2019 dimana dari peraturan tersebut dipaparkan salah satunya yaitu peningkatan penataan perkotaan/perdesaan, bangunan gedung dan kualitas lingkungan permukiman dan perumahan tentang arah kebijakan yaitu penataan wilayah perkotaan (PKL). Dan diperkuat dengan Peraturan Daerah Kabupaten Garut Nomor 12 Tahun 2015 tentang Ketertiban, Kebersihan, dan Keindahan.

Upaya penataan dan penertiban PKL yang dilakukan oleh Pemerintah Garut yaitu dengan merelokasi PKL terutama yang berada di zona merah ke Gedung PKL yang berada di Jalan Guntur dan Jalan Ciwalen. Walaupun demikian, dalam menata PKL ini tentunya tidak mudah.

Permasalahan yang dihadapi dalam program relokasi PKL di Kabupaten Garut antara lain:

1. Bangunan yang telah disediakan oleh Pemerintah Garut untuk PKL terbengkalai, belum dimanfaatkan secara efektif.

2. Relokasi PKL dianggap menurunkan peluang dan pendapatan sehingga banyak PKL yang mencoba kembali berjualan lagi di zona merah bahkan jumlahnya semakin bertambah.

3. Terjadinya kesemrawutan Kota, mengganggu pejalan kaki, lalu lintas 
Kolaborasi : Jurnal Administrasi Publik, Desember 2019 Volume 5 Nomor 3

yang tidak teratur, keindahan kota terganggu bahkan terkesan kumuh.

4. PKL yang direlokasi tidak seimbang dengan ketersediaan gedung.

Sejalan dengan pokok permasalahan di atas, maka penelitian ini bertujuan untuk mengetahui data dan informasi tentang:

a) Evaluasi kebijakan program relokasi PKL di Garut Kota.

b) Faktor-faktor yang menjadi penghambat dalam merelokasi PKL di Garut Kota.

Dengan dilakukannya penelitian ini diharapkan akan mampu memberikan kontribusi pada pemerintah Kabupaten Garut tentang solusi terkait masalah PKL yang tidak kunjung terselesaikan ini sehingga keindahan kota Garut akan terjaga.

\section{METODE}

Metode penelitian yang digunakan dalam penelitian ini adalah metode kualitatif. Melalui metode kualitatif, peneliti dapat mengeksplorasi dan memahami makna dari partisipan maupun fenomena-fenomena sosial kemudian mengumpulkan data dan informasi yang spesifik mengenai program relokasi PKL di Garut Kota. Adapun dalam mengembangkan dan menggambarkan penelitian, peneliti menggunakan pendekatan penelitian deskriptif.

Penelitian ini dilaksanakan di Pusat Garut Kota, khususnya di lokasi yang menjadi zona merah yang banyak ditempati PKL yaitu di Jln. Ahmad Yani, Jln. Siliwangi dan Jln. Ciledug serta dua Gedung PKL yang terletak di Jln. Guntur dan Jln. Ciwalen. Pemilihan lokasi tersebut sebagai lokasi penelitian yaitu karena isu mengenai PKL dan dua Gedung relokasi yang terbengkalai sedang ramai diperbincangkan, dan terbukti dengan semakin menjamurnya PKL di area zona merah.

Teknik pengambilan sumber data yaitu snowball yang ditentukan secara purposive, dengan informan kunci yaitu Koordinator PKL UPT Disperindag ESDM Kabupaten garut. Secara lebih rinci informan penelitian dapat dilihat pada tabel berikut:

\section{Tabel 2}

\section{Informan Penelitian}

\begin{tabular}{|c|c|c|}
\hline No & Informan & $\begin{array}{r}\text { Jumlah } \\
\text { (orang) }\end{array}$ \\
\hline 1 & 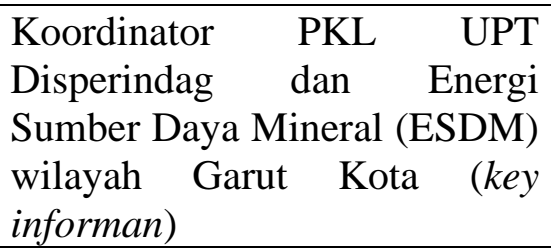 & 1 \\
\hline 2 & $\begin{array}{l}\text { Kabid Perdagangan Dinas } \\
\text { Perindustrian dan Perdagangan } \\
\text { Kabupaten Garut }\end{array}$ & 1 \\
\hline 3 & $\begin{array}{l}\text { Ketua Lembaga Pedagang } \\
\text { Kaki Lima (LPKLG) }\end{array}$ & 1 \\
\hline 4 & Satpol PP & 2 \\
\hline 5 & $\begin{array}{l}\text { Pedagang Kaki Lima di Garut } \\
\text { Kota yang berjualan di area } \\
\text { zona merah }\end{array}$ & 4 \\
\hline 6 & $\begin{array}{l}\text { Masyarakat sebagai konsumen } \\
\text { PKL }\end{array}$ & 4 \\
\hline & Total & 13 \\
\hline
\end{tabular}

Teknik pengumpulan data penelitian ini dilakukan melalui observasi secara langsung ke lapangan tepatnya di tempat-tempat yang 
Kolaborasi : Jurnal Administrasi Publik, Desember 2019 Volume 5 Nomor 3

menjadi titik PKL menjajakan dagangannya di zona merah sekitar Garut Kota. Lalu wawancara dengan pertanyaan-pertanyaan yang terbuka mengenai program relokasi PKL. Serta studi dokumentasi melalui dokumen-dokumen penting, catatan harian, peraturan, kebijakan dan sebagainya yaitu dengan cara menganalisis dan mengkaji data-data secara mendalam mengenai program relokasi PKL di Garut Kota. Sementara tehnik analisis data dalam penelitian ini terdiri dari tiga tahapan yaitu Data reduction (Reduksi Data), Data Display (Penyajian Data) dan Conclusion Drawing/Verification

\section{HASIL DAN PEMBAHASAN}

\section{Evaluasi Kebijakan Program Relokasi PKL di Garut Kota}

Keberadaan Pedagang Kaki Lima (PKL) di Garut Kota sama halnya seperti di kotakota lain yaitu muncul dikarenakan kurangnya lapangan pekerjaan. Berdasarkan data yang tercatat di Dinas Perindustrian Perdagangan dan Energi Sumber Daya Mineral (Disperindag ESDM) Kabupaten Garut, jumlah PKL di kawasan pusat Garut Kota saat ini berkembang pesat mencapai angka 1.448 PKL pada tahun 2017-2019 khususnya yang berada di Garut Kota.

Berikut tabel jumlah PKL Garut Kota dari tahun 2017-2019:
Tabel 3

Jumlah PKL Garut Kota Tahun 2017-2019

\begin{tabular}{|c|c|c|}
\hline No & Uraian & Jumlah \\
\hline 1 & $\begin{array}{l}\text { Jalur Alun-alun antara } \\
\text { gerbang Pendopo s/d gerbang } \\
\text { Mesjid Agung }\end{array}$ & 63 \\
\hline 2 & $\begin{array}{l}\text { Jalur Siliwangi } 1 \text { Antara Jl. } \\
\text { Dewi Sartika ( LP ) s/d RM. } \\
\text { AMPERA }\end{array}$ & 125 \\
\hline 3 & $\begin{array}{l}\text { Jalur Siliwangi } 2 \text { belokan } \\
\text { Telkom-RM. AMPERA s/d } \\
\text { Belokan Cikuray-Belokan } \\
\text { Jalan Muhammadiyah }\end{array}$ & 96 \\
\hline 4 & $\begin{array}{l}\text { Jalur Cikuray antara Telkom- } \\
\text { Belokan Kantor Pos s/d Toko } \\
\text { Liong-Cahaya Agung } \\
\text { Belokan Siliwangi }\end{array}$ & 56 \\
\hline 5 & $\begin{array}{l}\text { Jalur Ciledug } 1 \text { antara Toko } \\
\text { Besi LIK KUN TAT -Aman } \\
\text { Abadi s/d Apotek Panca- } \\
\text { Toko Cahaya Agung }\end{array}$ & 96 \\
\hline 6 & $\begin{array}{l}\text { Jalur Ciledug II Antara } \\
\text { Gunung Putri-PKPN s/d } \\
\text { Makmur Jaya- Rumah Makan } \\
\text { Bunga Tanjung }\end{array}$ & 97 \\
\hline 7 & $\begin{array}{l}\text { Jalur A.Yani I Antara } \\
\text { Belokan Ciwalen Toko Buti } \\
\text { s/d Belokan Pasar Baru Toko } \\
\text { Tiga }\end{array}$ & 123 \\
\hline 8 & $\begin{array}{l}\text { Jalur A. Yani II Antara Toko } \\
\text { Julung s/d Asia Toserba } \\
\text { Belokan Bratayudha }\end{array}$ & 143 \\
\hline 9 & $\begin{array}{l}\text { Jalur A. Yani III Antara } \\
\text { Belokan Mas Rohmat s/d } \\
\text { Toko Patimah Belokan } \\
\text { Mandalagiri }\end{array}$ & 107 \\
\hline 10 & $\begin{array}{l}\text { Jalur A. Yani IV antara Toko } \\
\text { Liong- Sumatra s/d Belokan } \\
\text { BNI-Wansamin }\end{array}$ & 86 \\
\hline 11 & J1. Pasar Baru A s/d F & 295 \\
\hline 12 & $\begin{array}{l}\text { Jalur Mandalagiri Batas } \\
\text { Belokan Mandalagiri s/d } \\
\text { Belokan Darekdok }\end{array}$ & 161 \\
\hline & Jumlah & 1448 \\
\hline
\end{tabular}


Kolaborasi : Jurnal Administrasi Publik, Desember 2019 Volume 5 Nomor 3

PKL tersebut diatas terbagi menjadi tiga kelompok yaitu: 1) Bodasan atau pakaian, 2) Makanan dan 3)Buah-buahan.

Pertumbuhan jumlah PKL di Kabupaten Garut khususnya di pusat Garut Kota dari tahun ke tahun mengalami peningkatan. Hal tersebut dapat terlihat dari kondisi zona merah atau area yang dilarang oleh Pemerintah Kabupaten Garut yakni Jalan Ahmad Yani, Jalan Siliwangi, Jalan Ciledug dan sebagainya bahwa terdapat banyak PKL yang menjamur dan menjajakan dagangannya hingga mereka menimbulkan permasalahan seperti mengurangi keindahan suatu kota dengan memasang tenda-tenda biru di atas trotoar yang dikhususkan untuk pejalan kaki sehingga membuat bahu jalan menyempit.

Menjamurnya PKL yaitu dikarenakan tingginya jumlah masyarakat Garut yang memilih menjadi seorang PKL. Latar belakang masyarakat Garut menjadi PKL khususnya di Garut Kota yaitu karena faktor ekonomi. Para PKL harus memenuhi kebutuhan hidup sehari-hari. Angka pengangguran yang tinggi dikarenakan ketersediaan lapangan pekerjaan di Garut yang masih kurang dan sebagian dari masyarakat Garut memiliki latar belakang pendidikan yang rendah sehingga dapat mempersulit untuk mendapatkan pekerjaan. Masyarakat harus memiliki tingkat kecakapan tinggi untuk mendapat perkerjaan baik dari sisi pendidikan maupun kemampuan, sedangkan masyarakat masih banyak yang belum mumpuni dalam hal tersebut. Menjadi PKL, dirasa tidak harus memiliki keahlian khusus dan tidak harus memiliki modal besar, modal yang relatif kecil dan keinginan untuk berdagang saja sudah cukup untuk menjadi PKL selain bisa menghasilkan uang untuk pemenuhan kehidupan sehari-hari. Hal tersebut yang menjadikan faktor atau penyebab utama masyarakat Garut terjun menjadi PKL.

Disamping itu penyediaan lapangan pekerjaan juga menjadi hambatan, bisa jadi saat ini banyak masyarakat yang tingkat pendidikannya cukup tinggi namun tidak berhasil dalam persaingan mendapatkan pekerjaan, selain karena lapangan pekerjaan yang masih sedikit sehingga pemerintah juga harus lebih berupaya membuka lapangan pekerjaan atau memfasilitasi peningkatan kualitas usaha kreatif bagi masyarakat yang berminat berwirausaha. Faktor ketenangan berjualan juga menjadi alasan kenyamanan sehingga PKL tidak harus berkeliling dan berpindah-pindah ke berbagai tempat untuk berjualan serta tidak harus menyewa sebuah ruko untuk berjualan merupakan salah satu alasan menjadi PKL, intinya PKL tidak memerlukan modal yang begitu besar.

Ketenangan berjualan PKL ini menjadi pertanyaan, zona merah jelas-jelas menjadi 
Kolaborasi : Jurnal Administrasi Publik, Desember 2019 Volume 5 Nomor 3

tempat yang dilarang bagi PKL namun PKL merasa tenang berjualan di sana, padahal saat ini sering diadakan relokasi atau revitalisasi oleh Satpol PP yang menertibkan keberadaan PKL di zona merah. Namun meski upaya Satpol PP dalam merevitalisasi selalu dilaksanakan, PKL juga sama saja karena selalu kembali lagi ke zona merah meskipun sudah berkali-kali dibubarkan.

Hal tersebut terjadi karena pusat Garut Kota merupakan lokasi zona merah yang banyak ditempati oleh para PKL karena salah satu alasannya yaitu strategis dan dekat dengan pusat keramaian juga area tersebut sebagai etalase Kabupaten Garut. Mulai dari supermarket, sekolah, semua jalur angkutan umum terpusat disana. Dengan berbagai macam permasalahan yang timbul akibat menjamurnya PKL di Garut Kota, maka Pemerintah Kabupaten Garut mengeluarkan kebijakan untuk mengatasi permasalahan dengan cara merelokasi PKL.

Suatu kebijakan yang telah diimplementasikan haruslah dilakukan pengevaluasian agar hasil dari kebijakan tersebut dapat dilihat dan dinilai seberapa jauh kebijakan yang sudah berjalan juga mengetahui berhasil atau tidaknya kebijakan tersebut. Di sini peneliti menggunakan teori dari Suchman (dalam Santosa, 2012:44) yang menggambarkan langkah-langkah evaluasi kebijakan yaitu : a. Mengidentifikasi tujuan-tujuan program yang akan dievaluasi.

b. Analisis terhadap masalah.

c. Deskripsi dan standarisasi kegiatan.

d. Pengukuran terhadap tingkatan perubahan yang terjadi.

e. Menentukan apakah langkah perubahan yang diamati merupakah akibat dari kegiatan tersebut atau karena penyebab lain.
f. Beberapa indikator untuk menentukan keberadaan suatu dampak.

Dari langkah-langkah evaluasi kebijakan tersebut akan peneliti uraikan dan jabarkan wawancara berdasarkan teori dengan para informan yang terkait sebagai berikut:

a. Mengidentifikasi tujuan-tujuan program yang akan dievaluasi

Perencanaan yang matang dengan menetapkan sebuah tujuan yang akan dicapai melalui suatu program merupakan suatu hal yang sangat penting untuk menentukan efesiensi dan efektifitas program dan SDM dalam mencapai keberhasilan suatu tujuan yang telah ditetapkan.

Peningkatan jumlah PKL di Kabupaten Garut telah berdampak pada terganggunya kelancaran lalu lintas, estetika, kesehatan lingkungan dan kebersihan serta fungsi prasarana kawasan perkotaan dan pejalan kaki yang merasa terganggu saat berjalan di 
Kolaborasi : Jurnal Administrasi Publik, Desember 2019 Volume 5 Nomor 3

trotoar. Agar fungsi-fungsi tersebut kembali sesuai dengan ketentuan dan peraturan perundang-undangan dengan tetap memperhatikan kepentingan umum, sosial, ekonomi, keamanan dan ketertiban, maka perlu dilakukan penertiban dan penataan lokasi PKL yang tidak sesuai peruntukannya.

Tujuan program relokasi PKL adalah untuk menciptakan tata kehidupan Garut yang aman, nyaman dan indah. Tujuan tersebut telah dicantumkan dalam Peraturan Daerah Kabupaten Garut Nomor 12 Tahun 2015 tentang Ketertiban, Kebersihan, dan Keindahan serta untuk penataan kota disisi lain supaya lebih PKL tertata baik dari segi bentuk bangunan dan sarana perdagangan.

b. Analisis terhadap masalah

PKL yang sudah dipindahkan ke Gedung PKL 1 dan 2 kembali lagi ke zona merah yaitu Jalan Siliwangi, Jalan Ahmad Yani dan Jalan Ciledug serta jumlah PKL yang semakin meningkat. Peningkatan jumlah PKL di Kabupaten Garut telah berdampak pada terganggunya kelancaran lalu lintas seperti kemacetan, terganggunya estetika, kesehatan lingkungan dan kebersihan serta banyak PKL yang semakin berdesakan menjajakan dagangannya secara sembarang serta mendirikan tenda-tenda semi permanen yang membuat Pusat Garut Kota terlihat kumuh, fungsi prasarana kawasan perkotaan atau fasilitas umum seperti trotoar atau bahu jalan yang semakin menyempit membuat pejalan kaki merasa terganggu saat berjalan. Selain itu masyarakat yang berbelanja pada PKL juga menambah kesemrawutan karena mereka biasanya memarkirkan kendaraan di pinggir jalan sehingga menambah kemacetan di pusat kota. Kemudian Gedung PKL yang dijadikan tempat untuk relokasi PKL kini kondisinya kosong terbengkalai.

c. Deskripsi dan standarisasi kegiatan

Dengan timbulnya permasalahanpermasalahan yang disebabkan oleh keberadaan PKL maka Pemerintah Kabupaten Garut berupaya untuk menata PKL. Maka dari itu, Pemerintah Daerah Kabupaten Garut menjadikan fokus penataan PKL yang harus diselesaikan demi kenyamanan semua masyarakat Garut juga untuk menciptakan Garut yang aman, nyaman dan indah. Dengan dikeluarkannya Peraturan Daerah Nomor 3 Tahun 2014 tentang Rencana Pembangunan Jangka Menengah Daerah (RPJMD) Kabupaten Garut Tahun 2014-2019, dimana dari peraturan tersebut dipaparkan mengenai visi, misi serta program yang akan direalisasikan oleh Bupati Garut salah satunya yaitu peningkatan penataan perkotaan/perdesaan, bangunan gedung dan kualitas lingkungan permukiman dan perumahan tentang arah kebijakan yaitu penataan wilayah perkotaan (PKL). Serta Peraturan Daerah Kabupaten Garut Nomor 12 Tahun 2015 tentang 
Kolaborasi : Jurnal Administrasi Publik, Desember 2019 Volume 5 Nomor 3

Ketertiban, Kebersihan, dan Keindahan. Upaya penataan dan penertiban PKL yang dilakukan oleh Pemerintah Kabupaten Garut yaitu dengan cara memindahkan atau merelokasi PKL.

Upaya penataan PKL yang dilaksanakan oleh Pemerintah Kabupaten Garut dengan cara merelokasi atau memindahkan PKL terutama yang berada di zona merah ke tempat yang telah disediakan dan dibangun oleh Pemerintah Kabupaten Garut.

Adapun tahapan-tahapan relokasi yaitu diantaranya terdiri dari sosialisasi, pengundian serta penempatan. Sebelum melakukan sosialiasi mengenai relokasi PKL, terlebih dahulu Pemerintah Kabupaten Garut membentuk tim yang berdasarkan dengan Keputusan Bupati Garut Nomor 511.23/Kep.790-Admrek/2014 tentang Pembentukan Tim Penataan dan Pemberdayaan Pedagang Kaki Lima Di Kabupaten Garut dan Keputusan Bupati Garut Nomor 511.3/Kep.201-Satpol PP/2015 tentang Pembentukan Tim Pengamanan Penertiban Pedagang Kaki Lima Di Wilayah Kabupaten Garut. Kedua tim tersebut terdiri dari berbagai lapisan aparatur Pemerintah Daerah dan juga struktur organisasi dan tugas pokok masingmasing tim sudah tertera dalam peraturan tersebut. Setelah tim terbentuk, lalu tim melakukan sosialisasi secara langsung mengenai program penataan atau relokasi
PKL, teknisnya yaitu semua PKL terutama yang berada di zona merah diundang oleh tim untuk menerima pengarahan dan pembinaan mengenai relokasi serta mengundang pemerintah daerah setempat seperti Camat, Koramil, Polsek, LPKLG, Kelurahan Ciwalen yang bertempat di Gedung PKL 1. Selanjutnya adalah ketika sosialisasi telah selesai kemudian pengundian kupon dilakukan oleh semua PKL. Pengundian ditentukan seperti arisan yaitu di kocok kemudian setelah itu akan ada kesepakatan untuk penomoran hasil dari pengundian. Untuk pengundian dilakukan di Kecamatan Garut Kota, yang mengatur adalah perwakilan PKL yaitu LPKLG karena yang lebih dekat dengan pedagang, diwakili dengan pembagian-pembagian sesuai daerah atau yang mau menempati agar tercipta keadilan. Lembaga Pedagang Kaki Lima Garut (LPKLG) adalah sebuah wadah untuk para PKL Garut agar dapat menyalurkan aspirasinya kepada Pemerintah Kabupaten Garut. Disperindag sebagai pencatat, setelah itu di BAP kan dengan pengundian di hadapan Polsek, kecamatan, desa, Kelurahan Sukamantri dan Ciwalen. Setelah PKL memegang nomor undian barulah mereka melakukan pemindahan untuk menempati Gedung PKL 1 dan 2 sesuai dengan urutan nomor yang didapat.

Gedung PKL yang dibangun pada tahun 2014-2015 oleh Pemerintah Kabupaten 
Kolaborasi : Jurnal Administrasi Publik, Desember 2019 Volume 5 Nomor 3

Garut bernama Gedung PKL Intan Medina Garut yang terdiri dari dua gedung. Pembangunan kedua gedung tersebut menghabiskan total dana sebesar Rp. 3 Milyar lebih. Gedung tersebut dianggap strategis oleh pemerintah karena dekat juga dengan lokasi para PKL sebelum dipindahkan. Gedung PKL 1 dan 2 sudah terisi oleh para PKL dan pada saat itu zona merah yang berada di pusat Garut Kota sudah bersih dengan para PKL yang menjajakan daganganya di trotoar, jalan lalu lintas lancar dan para pengguna jalan kaki menggunakan haknya tanpa ada gangguan apapun. Berselang waktu beberapa bulan, para PKL kembali lagi ke zona merah tersebut dan semakin bertambah banyak jumlahnya. Pemerintah pun menanggapi hal tersebut serta banyak sekali upaya yang dilakukan terhadap para PKL yang kembali lagi ke zona merah.

d. Pengukuran terhadap tingkatan perubahan yang terjadi

Upaya yang dilakukan Pemerintah Kabupaten Garut untuk mempromosikan Gedung PKL Intan Medina dengan tujuan mengenalkan kepada seluruh masyarakat Garut bahwa disana terdapat Gedung PKL dan menarik masyarakat agar bisa berbelanja dengan nyaman tanpa harus pergi ke pusat Garut Kota. Adapun upaya tersebut yaitu:
- Membagikan kupon atau voucher berbelanja kepada masyarakat

- Mengadakan festival marawis

- Mengadakan pertunjukan kesenian lokal yaitu pencak silat sekabupaten Garut

Berselang waktu kurang lebih 7 bulan, para PKL kembali lagi ke zona merah dan semakin bertambah banyak jumlahnya. Banyak PKL yang semakin berdesakan menjajakan dagangannya secara sembarang serta mendirikan tenda-tenda semi permanen untuk berjualan dan bahu jalan atau trotoar semakin menyempit membuat pejalan kaki merasa terganggu. Kemudian kondisi Gedung PKL sampai saat ini dibiarkan kosong terbengkalai. Pemerintah pun menanggapi hal tersebut serta berbagai upaya yang telah dilakukan terhadap para PKL yang kembali lagi ke zona merah.

e. Menentukan apakah langkah perubahan yang diamati merupakan akibat dari kegiatan tersebut atau karena penyebab lain.

Dengan dilaksanakannya relokasi PKL ke Gedung PKL Intan Medina membuat perubahan yang terjadi ternyata tidak seperti apa yang diharapkan oleh Pemerintah Garut dan masyarakat sekitar. Perwujudan kota yang aman, nyaman dan indah sudah jauh dari harapan. Berbagai upaya yang telah diterapkan dianggap masih belum mencapai hasil yang optimal. Para PKL yang 
Kolaborasi : Jurnal Administrasi Publik, Desember 2019 Volume 5 Nomor 3

direlokasi kembali lagi ke zona merah dan kini kondisi pusat Garut Kota semakin semrawut dan terkesan kumuh.

f. Beberapa indikator untuk menentukan keberadaan suatu dampak.

Adapun indikator untuk menentukan keberadaan suatu dampak dari relokasi PKL ini yaitu :

a) Tercapainya tujuan relokasi PKL yaitu ketertiban, keindahan serta kenyamanan bagi masyarakat sekitar serta pendatang dari luar atau wisatawan yang menggunakan fasilitas umum

Untuk menentukan keberadaan suatu dampak dapat dilihat dari Pemerintah Kabupaten Garut beserta masyarakatnya yang menginginkan tata kehidupan Garut yang aman, nyaman dan indah. Keberadaan PKL tentu membuat estetika keindahan menjadi tidak maksmimal, dan banyak masyarakat yang merasa terganggu akan hal itu. Namun pada kenyataannya masih ada sebagian masyarakat yang tidak memperdulikan nilai-nilai tersebut atau dapat dikatakan mendukung PKL berjualan di zona merah dengan tetap membeli dagangannya.

Sebagian masyarakat berpikiran bahwa adanya kemudahan untuk mencari suatu barang kemudian harga yang ditawarkan oleh PKL jauh lebih murah dibandingankan dengan harga toko, juga untuk kualitasnya pun tidak jauh beda diantara keduanya. Ada satu yang unik alasan masyarakat tetap berbelanja di PKL yaitu adanya sistem tawar menawar yang tidak ada di toko. Selain itu adanya PKL memberi kemudahan berbelanja, dengan barang dagangan yang terbuka lebih memberi peluang masyarakat berbelanja meskipun tidak niat membeli.

Disisi lain masyarakat yang menginginkan Garut tertata lebih baik merasakan sendiri bagaimana masalahmasalah yang muncul yang disebabkan oleh PKL. Hal tersebut dibenarkan oleh masyarakat sekitar yang menyetujui bahwa PKL harus direlokasi.

Keberadaan PKL dinilai sudah mengganggu estetika Garut, terlebih membuat lalu lintas menjadi semrawut dan terkesan kumuh, disamping itu juga keberadaannya sebagai roda perekonomian masyarakat bawah untuk memenuhi kebutuhan hidupnya. Semua masyarakat Garut harus bijak dalam menanggapi kebijakan yang telah ditetapkan demi tujuan bersama.

b) Tercapainya kenyamanan bagi PKL dalam melakukan kegiatan usaha

Selain untuk menciptakan Garut aman, nyaman dan indah, Pemerintah Kabupaten Garut pun tidak mengesampingkan kenyamanan bagi PKL sendiri. Dengan direlokasinya PKL ke Gedung PKL diharapkan PKL bisa lebih nyaman dalam berjualan tetapi kenyataannya berbanding 
Kolaborasi : Jurnal Administrasi Publik, Desember 2019 Volume 5 Nomor 3

terbalik. Dengan adanya kebijakan program ini, PKL justru merasa terganggu ditempatkan di Gedung PKL sehingga kembali lagi ke zona merah. Perbedaan paham ini menimbulkan permasalahanpermasalahan dan tujuan tidak tercapai secara optimal.

Untuk menanggapi kembalinya PKL dari Gedung PKL ke zona merah, Pemerintah Kabupaten Garut memberikan pertimbangan lain bagi PKL yaitu diantaranya memberikan tindak pidana ringan (tipiring) berupa denda kepada penjual maupun pembeli juga memberikan gerobak secara gratis untuk berjualan dengan alasan Senin sampai dengan Jumat di Gedung PKL dan Sabtu Minggu bisa berjualan di zona merah. Pada kenyataannya, aturan tersebut tidak berlaku. Setiap hari PKL berjualan di lokasi tersebut dan semakin banyak jumlahnya.

Disamping itu Pemerintah Kabupaten Garut memberikan penyuluhan sementara kepada PKL yaitu agar PKL tetap menjaga kebersihannya setiap hari dengan mengadakan OPSI atau Operasi Bersih yang dilaksanakan setiap hari Jumat bersama pengurus LPKLG, pedagang, pemerintah di Jalan Siliwangi dan titik zona merah lainnya. Pemerintah diharapkan cepat menata para PKL yang berjualan di zona merah agar rapi, tertib, dan tidak mengganggu arus lalu lintas kendaraan.
Program relokasi PKL yang telah diselenggarakan oleh Pemerintah Kabupaten Garut dapat dikatakan gagal. Dengan ini PKL menaruh harapan yang besar agar pemerintah mengubah programnya dari relokasi menjadi revitalisasi atau penataan saja.

Pemerintah perlu melakukan penataan dan mengatur PKL ditempat sebaik mungkin daripada menyelenggarakan program relokasi PKL yang memang tidak diterima oleh PKL. Dengan penataan dan melakukan penyeragaman PKL, tidak akan menimbulkan permasalahan dan menciptakan keindahan.

Kondisi Gedung PKL yang dibiarkan kosong terbengkalai juga harus segera ditindaklanjuti. Sebelumnya peneliti akan memberikan penjelasan bahwa yang mengurus Gedung PKL adalah LPKLG. Dengan dikeluarkannya Surat Keputusan Bupati Garut Nomor 028/Kep.700.DPPKA/2016 tentang Penetapan Status Penggunaan Barang Milik Daerah Untuk Dioperasikan Oleh Lembaga Pedagang Kaki Lima Garut bahwa LKPLG berkewajiban untuk menata dan merelokasi pedagang yang berada pada tanah dan bangunan yang dioperasikan, memelihara dan mengamankan Barang Milik Daerah. Sementara dalam SK ini tugas Disperindag Kabupaten Garut hanya sebagai pengawas 
Kolaborasi : Jurnal Administrasi Publik, Desember 2019 Volume 5 Nomor 3

dan pengendali terhadap Barang Milik Daerah.

Jika LPKLG sudah tidak mampu maka lakukanlah langkah-langkah yang sesuai dengan aturan yaitu dengan pelimpahan penggunaan Gedung PKL oleh LPKLG kepada Pemerintah Kabupaten Garut, agar Disperindag sendiri selaku dinas bisa memanfaatkan Gedung PKL tersebut. Kenyataannya pelimpahan wewenang sudah dilakukan hanya saja tidak diterima oleh Bupati sendiri selaku pembuat keputusan. Hal tersebut mengakibatkan Gedung PKL menjadi tidak jelas peruntukkannya.

Maka saat ini ujung tombak dari keputusan Bupati tentang penggunaan gedung relokasi itu ada pada Bupati Garut sendiri, sedangkan untuk PKL saat ini, per bulan Juni 2019 Satpol PP kembali melakukan revitalisasi secara bertahap di Jalan Ahmad Yani sampai pertigaan Jalan Ciledug, dan revitalisasi total sampai dengan Jalan Ahmad Yani yang berpatok di Asia, seluruh PKL sudah tidak terlihat lagi, setiap hari pun selalu ada pengamanan dari Satpol PP.

Setiap daerah memiliki karakter masingmasing, studi banding bisa bermanfaat namun tetap harus melihat dari sisi karakter masyarakat juga, selain itu perekonomian akan lebih stabil dengan adanya PAD yang bisa didapat dari PKL. Meski begitu, pemerintah daerah juga tidak bisa serta merta mewujudkan keinginan PKL, harus ada pengkajian terlebih dahulu terkait zona merah dan pengukuran tata kota, penertiban parkir di sekitar zona merah, dan lain-lain.

\section{Faktor-faktor yang Menjadi \\ Penghambat dalam Merelokasi PKL di Garut Kota.}

Berdasarkan hasil dari penelitian, terdapat faktor-faktor yang mempengaruhi relokasi sehingga tidak berjalan dengan lancar. Faktor-faktor tersebut antara lain yatu:

a) Kurang begitu laku dan sepi pembeli. Mindset warga takut rugi, jadi kalau tidak berjualan di sana barang dagangan tidak akan laku.

b) Infrastruktur yang tersedia tidak memungkinkan untuk dilakukan pelebaran jalan/trotoar maka memang tidak ada space untuk PKL sehingga kehadiran PKL mengganggu ketertiban pejalan kaki.

c) Mindset Petugas: Seringkali mengalami titik jenuh akan tugas menertibkan dan kenakalan PKL yang terus kembali ke zona merah.

d) Sarana dan prasarana relokasi masih belum memadai dan belum memfasilitasi semuia PKL yang ada di Kabupaten Garut.

e) Kurangnya sinergitas antara Satpol PP, PUPR, Stakeholder, dll. 
Kolaborasi : Jurnal Administrasi Publik, Desember 2019 Volume 5 Nomor 3

f) Warga masih senang bertransaksi di PKL sehingga memperkuat PKL untuk kembali ke zona merah, enggan berpindah ke tempat relokasi.

g) PKL tidak setuju dengan program relokasi

h) Sosialisasi yang dilakukan hanya sosialisasi terkait pemindahan ke Gedung PKL saja bukan mengenai perencanaan pembangunan Gedung PKL. Untuk pembinaan PKL pun, pemerintah kurang gencar melakukannya.

\section{KESIMPULAN}

Berdasarkan hasil penelitian yang telah dikemukakan, maka peneliti dapat menarik kesimpulan bahwa Kebijakan Program Relokasi Pedagang Kaki Lima (PKL) di pusat Garut Kota dapat dikatakan belum efektif dikarenakan belum mencapai tujuan yang telah ditetapkan sebelumnya. Tujuan program relokasi PKL adalah untuk menciptakan tata kehidupan Garut yang aman, nyaman dan indah; tercantum dalam Peraturan Daerah Kabupaten Garut Nomor 12 Tahun 2015 tentang Ketertiban, Kebersihan, dan Keindahan. Setelah sempat pindah berjualan di gedung relokasi dalam beberapa waktu yg singkat, PKL malah kembali berjualan pada zona merah di pusat Garut Kota bahkan jumlah PKL semakin meningkat. Hal ini berdampak pada terganggunya kelancaran lalu lintas, estetika, kesehatan lingkungan dan kebersihan serta fungsi prasarana di kawasan perkotaan seperti trotoar atau bahu jalan yang semakin menyempit sehingga membuat pejalan kaki merasa terganggu saat berjalan.

Selain itu, gedung PKL yang dijadikan tempat untuk relokasi PKL kini kondisinya kosong terbengkalai. Berbagai upaya telah dilakukan oleh Pemerintah Kabupaten Garut untuk mengatasi hal tersebut, tetapi tetap saja PKL kembali lagi ke zona merah. Adapun yang menjadi penyebab kembalinya PKL ke zona merah atau penghambat relokasi adalah ketidak setujuan PKL terhadap kebijakan program relokasi ini dan kurang begitu laku dan sepi pembeli yang mengakibatkan penurunan pendapatan PKL secara dratis. Dengan kata lain program relokasi tidak sesuai dengan target pasar mereka. Hal ini sejalan dengan temuan penelitian Utomo (2014) tentang Studi Deskriptif Tentang “Studi Deskriptif tentang Faktor-Faktor Penyebab Kegagalan Program Relokasi PKL di Area Stadion Tambaksari Surabaya".

Adapun rekomendasi penelitian ini yaitu bagi Pemerintah Kabupaten Garut hendaknya dapat melakukan pembinaan dan pemberdayaan secara berkelanjutan kepada para PKL, mengadakan forum diskusi antara PKL dan Pemerintah Kabupaten Garut untuk mencari solusi bersama dalam 
Kolaborasi : Jurnal Administrasi Publik, Desember 2019 Volume 5 Nomor 3

mengatasi relokasi yang tidak efektif ini dan hendaknya gedung relokasi segera diambil alih oleh Bupati agar dapat dimanfaatkan dan dikelola lebih baik lagi. Selain itu para PKL hendaknya meningkatkan kesadarannya untuk mematuhi aturan, berjualan dengan tertib dan teratur dengan menjaga kebersihan, tidak berjualan di sekitar zona merah dan tidak mengganggu fasilitas umum. Diharapkan PKL dan Pemerintah Kabupaten Garut dapat saling bekerjasama untuk mewujudkan tata kehidupan Garut yang aman, nyaman dan indah.

\section{UCAPAN TERIMAKASIH}

Terimakasih sebesar-besarnya kepada Kemenristek Dikti yang telah menjadi sponsor penelitian ini. Terimakasih pula kami ucapkan kepada Disperindag Kabupaten Garut, Sat Pol PP Kabupaten Garut, Ketua LPKLG serta pihak-pihak lain yang telah berkontribusi dengan memberikan informasi penting terkait penelitian ini.

\section{REFERENSI}

Agustino, L. (2017). Dasar-dasar Kebijakan Publik. Bandung: Alfabeta.

Ali, F., \& Alam, A. S. (2016). Studi Kebijakan Pemerintah. Bandung: PT Refika Aditama.

Batlajeri, T. G., \& Sukaesih, P. (2016). Evaluasi Kebijakan Penataan Dan
Pembinaan Pedagang Kaki Lima (PKL) Di Kota Bandung.

Bukhari. (2017). Pedagang Kaki Lima (PKL) dan Jaringan Sosial: Suatu Analisis Sosiologi . Jurnal Sosiologi USK. 83.

Creswell, J. W. (2013). Research Design Pendekatan Kualitatif, Kuantitatif dan Mixed. Yogyakarta: Pustaka Pelajar.

Dunn, W. N. (2003). Pengantar Analisis Kebijakan Publik. Yogyakarta: Gadjah Mada University Press.

Fermana, S. (2009). Kebijakan Publik: Sebuah Tinjauan Filosofis. Yogyakarta: Ar-Ruzz Media.

Ihsan, A. M. (2017, Agustus 30). Bangunan Miliaran Dibiarkan Kosong. Dipetik Mei 11, 2018, dari Pikiran Rakyat: http://www.pikiran-rakyat.com/suratpembaca/2017/08/30/bangunanmiliaran-dibiarkan-kosong-408347

Keputusan Bupati Garut Nomor 511.23/Kep.790-Admrek/2014 tentang Pembentukan Tim Penataan dan Pemberdayaan Pedagang Kaki Lima Di Kabupaten Garut

$\begin{array}{lrr}\text { Keputusan Bupati Garut } & \text { Nomor } \\ \text { 511.3/Kep.201-Satpol } & \text { PP/2015 } \\ \text { tentang } & \text { Pembentukan } & \text { Tim } \\ \text { Pengamanan } & \text { Penertiban } & \text { Pedagang } \\ \text { Kaki Lima } & \text { Di Wilayah } & \text { Kabupaten } \\ \text { Garut. } & & \end{array}$

Moleong, L. J. (2001). Metodologi Penelitian Kualitatif. Bandung: PT Remaja Rosdakarya.

Pasolong, Harbani. (2017). Teori Administrasi Publik. Bandung: Alfabeta

Peraturan Daerah Nomor 3 tahun 2014 tentang Rencana Pembangunan Jangka Menengah (RPJMD) Kabupaten Garut

Peraturan Daerah Kabupaten Garut Nomor 12 Tahun 2015 tentang Ketertiba, Kebersihan dan Keindahan 
Kolaborasi : Jurnal Administrasi Publik, Desember 2019 Volume 5 Nomor 3

Puspitasari, D. E. (2010). Penataan Pedagang Kaki Lima Kuliner untuk Mewujudkan Fungsi Tata Ruang Kota di Kota Yogyakarta dan Kabupaten Sleman. Mimbar Hukum, 588.

Ramdhan, K. M., Sumaryana, A., \& Ismanto, S. U. (2007). Pemantauan Kebijakan Penataan Pedagang Kaki Lima Di Kecamatan Garut Kota Oleh Tim Penataan dan Pemberdayaan Pedagang Kaki Lima Kabupaten Garut. Jurnal Administrasi Negara, 2930 .

Santosa, P. (2012). Administrasi Publik Teori dan Aplikasi Good Governance. Bandung: Refika Aditama.

Subarsono, A. (2013). Analisis Kebijakan Publik Konsep, Teori dan Aplikasi. Yogyakarta: Pustaka Pelajar .

Sugiyono. (2017). Metode Penelitian Kombinasi. Bandung: Alfabeta.

Sugiyono. (2017). Metode Penelitian Kuantitatif, Kualitatif dan R\&D. Bandung: Alfabeta.

Surat Keputusan Bupati Garut Nomor 028/Kep.700.DPPKA/2016 tentang Penetapan Status Penggunaan Barang Milik Daerah Untuk Dioperasikan
Oleh Lembaga Pedagang Kaki Lima Garut

Suripto, R. (2017). Resistensi Pedagang Kaki Lima Dalam Implementasi Kebijakan Di Kecamatan Wiyun. Jurnal Politik Muda, Vol. 6, No. 3, 195.

Sutarjo. (2016). Street Vendors Exterbalities Vol 1. Jurnal AdBispreneur, 1-8.

Sutopo. (2002). Metodologi Penelitian Kualitatif. Surakarta: UNS Press.

Utomo, F. R. (2014). Studi Deskriptif Tentang Faktor-Faktor Penyebab Kegagalan Program Relokasi PKL di Area Stadion Tambaksari Surabaya . Kebijakan dan Manajemen Publik, Volume 2, Nomor 1.

Widodo, A. S., Idayanti, S., Permanasari, D. I., \& Sahri, A. (2016). Kebijakan Relokasi Pedagang Kaki Lima (PKL) di Kawasan Kota Tegal. Jurnal Ilmu Pemerintahan : Kajian Ilmu Pemerintahan dan Politik Daerah, 185.

Winarno, B. (2007). Kebijakan Publik Teori dan Proses. Yogyakarta. Media Presindo 